\title{
Efektywność działania nowoczesnych koagulantów glinowych w warunkach obniżonego pH wód z formacji łupkowych
}

\begin{abstract}
Prawidłowe przeprowadzenie procesu koagulacji zanieczyszczeń pociąga za sobą pewne problemy związane z drastyczną zmianą równowagi chemicznej wywołaną odgazowaniem i napowietrzeniem wydobytej wody złożowej. Przebiegające procesy red-ox mogą przyczyniać się do zakwaszenia oczyszczanej wody, co powoduje przesunięcie odczynu poza dopuszczalny zakres dla prawidłowego przeprowadzenia procesu koagulacji. W artykule opisano badania laboratoryjne dotyczące zastosowania nowoczesnych koagulantów, chlorków poliglinu, wytypowanych pod kątem poszerzenia optymalnego zakresu odczynu oczyszczanej wody złożowej. Testowane środki wykazały znacznie wyższą w porównaniu z siar-

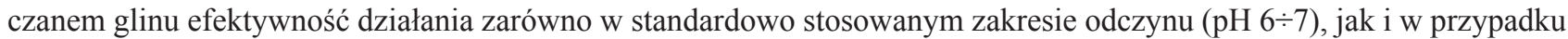
środowiska lekko kwaśnego ( $\mathrm{pH} 5,0)$.
\end{abstract}

Słowa kluczowe: koagulacja, chlorki poliglinu, odczyn koagulacji.

\section{Effectiveness of advanced coagulants - polyaluminium chlorides in conditions of decreased reaction of water from shale formations}

\begin{abstract}
A properly conducted process of coagulation pollution entails some problems associated with the drastic change of the chemical balance induced by demethanization and aeration of formation water. Red-ox processes might lead to the acidizing of water, which result in reaction displacement over the acceptable range of coagulation. The aim of the article is to present laboratory research on the application of advanced pollutants, polyaluminium chlorides, selected in order to extend the optimum range of the reaction for water treatment. The tested substances have shown considerably higher effectiveness (in comparison to aluminium sulphate) both in the standard use of reaction range (pH $6 \div 7$ ) and in the case of a slightly acid environment ( $\mathrm{pH}$ 5.0).
\end{abstract}

Key words: coagulation, polyaluminium chlorides, coagulation reaction.

\section{Wprowadzenie}

W trakcie eksploatacji złóż węglowodorów z poziomów łupkowych wraz z gazem ziemnym i ropą naftową wydobywane są wody złożowe (solanki), składem zbliżone do wód uzyskiwanych ze złóż konwencjonalnych. Zawierają wiele substancji organicznych i nieorganicznych, których obecność w głównej mierze zależy od budowy kolektora skalnego oraz geologicznego pochodzenia płynów złożowych. Dodatkowym aspektem jest wzbogacanie wód złożowych w różnego rodzaju związki chemiczne stosowane w trakcie eksploatacji (inhibitory korozji, hydratów, parafin oraz środki pieniące itp.), a także substancje powstające podczas kontak- tu wysoko zmineralizowanej wody z materiałem orurowania odwiertu i instalacji napowierzchniowych (głównie produkty korozji). Ponadto ilości substancji obecnych w wodzie mogą zmieniać się w bardzo szerokich granicach, w zależności od warunków eksploatacji. $Z$ tego powodu zagospodarowanie wód złożowych wydobytych podczas eksploatacji złóż węglowodorów generuje liczne problemy związane zarówno z różnorodnością zanieczyszczeń, jak i dużą zmiennością ich zawartości.

Najczęściej stosowanym i najbardziej ekonomicznym rozwiązaniem jest usunięcie wód złożowych z aktywnej biosfery 
poprzez zatłoczenie do wyeksploatowanych horyzontów chłonnych (jako powrotne zatłaczanie lub bezzbiornikowe magazynowanie odpadów płynnych w górotworze) albo wykorzystanie ich do nawadniania złóż w procesach wspomagających eksploatację. W celu ochrony odwiertu chłonnego przed kolmatacją podczas zatłaczania wody konieczne jest stosowanie metod oczyszczania, które pozwolą na usunięcie niepożądanych substancji: osadów i zawiesin, jonów żelaza i manganu, węglowodorów ropopochodnych i ewentualnie innych składników mogących powodować niekorzystne oddziaływanie na strefę przyodwiertową [2, 9, 10, 14].

Jedną z technik wykorzystywanych podczas klasycznego procesu oczyszczania wód jest koagulacja. Proces koagulacji to łączenie cząstek koloidalnych w większe aglomeraty - po dodaniu do wody koagulanta, ewentualnie również flokulanta, które są odpowiedzialne za tworzenie się kłaczków, a następnie usunięcie ich z wody w procesie sedymentacji lub flotacji oraz filtracji. Destabilizacja koloidów przebiegająca podczas koagulacji jest wynikiem kilku mechanizmów [3], które zależą w dużej mierze od rodzaju i stężenia usuwanych koloidów, wartości pH i dawki stosowanego koagulanta. Mechanizmami tymi są:

- destabilizacja elektrostatyczna (zobojętnienie ładunku),

- mostkowanie - aglomeracja cząstek koloidalnych na obecnych w wodzie polimerach organicznych,

- współstrącanie (tzw. koagulacja zmiatająca) - zachodząca w zakresie $\mathrm{pH}$, przy którym wodorotlenki stosowanych koagulantów charakteryzują się najniższą rozpuszczalnością.

Skuteczne przeprowadzenie procesu koagulacji stwarza pewne problemy związane $\mathrm{z}$ fizykochemicznym charakterem wydobytych wód złożowych oraz przemianami zachodzącymi w trakcie procesu przygotowania ich do zatłoczenia odwiertem chłonnym.

Po wydobyciu wody złożowej na powierzchnię następuje jej odgazowanie, a następnie natlenienie (w przypadku większości kopalń), co drastycznie zmienia środowisko chemicz- ne wody z silnie redukcyjnego na utleniające. Jest to przyczyną przebiegu wielu reakcji chemicznych powodujących zmiany stopnia utlenienia niektórych jonów i umożliwiających wytrącanie się osadów i zawiesin. Przebieg tych reakcji wywołuje również zmiany odczynu wody, co także przyczynia się do zaburzenia równowagi chemicznej.

W wyniku kontaktu wody o wysoce korozyjnych właściwościach z materiałem konstrukcyjnym orurowania odwiertów i instalacji napowierzchniowych atomy metali (głównie żelaza i manganu) przechodzą w formie jonowej do roztworu, co pociąga za sobą dalsze reakcje chemiczne, które w efekcie skutkują powstawaniem osadów tlenków i wodorotlenków.

Ze względu na dużą zmienność zawartości poszczególnych substancji w wodach złożowych przeprowadzenie ich oczyszczania może sprawić spore problemy. Pierwszym z nich jest konieczność usunięcia jonów żelaza, co realizowane jest najczęściej poprzez odpowiednie napowietrzenie partii wody w celu wytrącenia wodorotlenków i tlenków. W trakcie tego etapu korygowany jest także odczyn wody

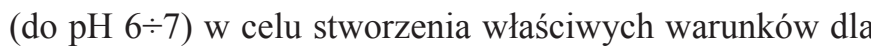
kolejnego etapu oczyszczania, jakim jest koagulacja. Niestety korekta ta dokonana przed utlenieniem większości żelaza może okazać się niewystarczająca, ponieważ w takcie procesu zachodzą reakcje red-ox (utlenienie $\mathrm{z} \mathrm{Fe} \mathrm{Fe}^{+2} \mathrm{de}^{+3}$ ) i reakcje hydratacji powodujące zakwaszenie wody w myśl ogólnego równania:

$$
\mathrm{Fe}^{3+}+3 \mathrm{H}_{2} \mathrm{O} \rightarrow \mathrm{Fe}(\mathrm{OH})_{3} \downarrow+3 \mathrm{H}^{+}
$$

Dodatkowy wpływ na zmiany odczynu mają procesy korozji oraz dozowanie dużych ilości koagulantów, które charakteryzują się odczynem kwaśnym i także hydrolizują, „zużywając" zasadowość ogólną wody.

W celu obniżenia wymogów dotyczących odczynu wody w procesie koagulacji przebadano kilka nowoczesnych koagulantów wytypowanych pod kątem zwiększenia skuteczności koagulacji oraz rozszerzenia zakresu odczynu wody w kierunku niskiego $\mathrm{pH}$.

\section{Ogólna charakterystyka nowoczesnych koagulantów - chlorków poliglinu}

W świetle doniesień literaturowych okazuje się, że jednym ze sposobów intensyfikacji koagulacji, a jednocześnie minimalizacji niepożądanych skutków procesu, jest zastąpienie tradycyjnie stosowanych koagulantów koagulantami wstępnie zhydrolizowanymi. Cechą odróżniającą je od koagulantów niezhydrolizowanych jest to, że zawierają one grupy hydroksylowe decydujące o ich zwiększonej zasadowości $[12,13,16]$. Wśród koagulantów wstępnie zhydrolizowanych obecnych na polskim rynku najczęściej dostępne są chlorki poliglinu o zasadowości od 26 do $85 \%$, o nazwach handlo- wych: PAX, PAC, WAC, PALS, FLOCOR itp. Poza chlorkami poliglinu do koagulantów wstępnie zhydrolizowanych należą również siarczany(VI) poliglinu oraz poliżelaza(III). Obecnie na świecie zużywa się około 2000000 ton chlorków poliglinu i przewiduje się, że w najbliższym czasie, ze względu na ich dużą efektywność w usuwaniu zanieczyszczeń oraz mniejszą wrażliwość na zmiany temperatury i odczynu oczyszczanej wody, ich zużycie znacznie wzrośnie.

Chlorki poliglinu o ogólnym wzorze $\mathrm{Al}_{\mathrm{n}}(\mathrm{OH})_{\mathrm{m}} \mathrm{Cl}_{3 \mathrm{n}-\mathrm{m}}$ [17] charakteryzują się zwiększoną alkalicznością w zakresie od 15 
do 85\% [6]. O zasadowości chlorków poliglinu decyduje iloraz liczby moli $\mathrm{OH}^{-}: \mathrm{Al}^{3+}$ w koagulancie, określany jako współczynnik alkaliczności (r) i traktowany jako miara stopnia polimeryzacji. Zachodząca podczas produkcji chlorków poliglinu wstępna hydroliza powoduje, że koagulanty te zawierają znacznie więcej spolimeryzowanych form glinu o dużym dodatnim ładunku w porównaniu z produktami hydrolizy koagulantów niezhydrolizowanych wstępnie.

Spośród metod produkcji chlorków poliglinu stosowanych na skalę przemysłową najefektywniejsza jest synteza elektrochemiczna pozwalająca na ścisłą kontrolę warunków procesu zgodnie z następującym równaniem:

$$
\mathrm{n} \mathrm{Al}+3 \mathrm{n} \mathrm{H}_{2} \mathrm{O}+\mathrm{m} \mathrm{AlCl}_{3 \rightarrow} \mathrm{Al}_{\mathrm{m}+\mathrm{n}}(\mathrm{OH})_{3 \mathrm{n}} \mathrm{Cl}_{3 \mathrm{~m}}+1,5 \mathrm{n} \mathrm{H}_{2}
$$

Według Edzwalda i Van Benschotena [7] ilość monomerów w rozworach chlorków poliglinu jest różna i zależy głównie od wartości współczynnika alkaliczności koagulantów $\left(\mathrm{r}=\left[\mathrm{OH}^{-}\right] /\left[\mathrm{Al}^{3+}\right]\right)$. Wzrost alkaliczności chlorków poliglinu $(\mathrm{r})$ od 0 do 2 powoduje, że formą dominującą w ich roztworach jest polimer o 13 atomach glinu, o wzorze $\left[\mathrm{Al}_{13} \mathrm{O}_{4}(\mathrm{OH})_{24}\right]^{7+}$, natomiast dla $\mathrm{r}>2,1$ udział polimerów $\mathrm{Al}_{13}$ zaczyna maleć, ponieważ wytrącają się one w postaci wodorotlenku glinu. Opinie badaczy na temat rodzaju produktów hydrolizy koagulantów wstępnie zhydrolizowanych są różne, wszyscy wyrażają jednak zgodny pogląd, że w powstających hydroksykompleksach glinu stosunek liczby moli $\mathrm{OH}^{-}: \mathrm{Al}^{3+}$ jest mniejszy od 3,0, co oznacza, że wśród produktów hydrolizy chlorków poliglinu oprócz $\mathrm{Al}(\mathrm{OH})_{3}$ obecne są również monomery i polimery glinu przedstawione w tablicy 1 .

Spośród polimerów glinu obecnych w roztworach koagulantów wstępnie zhydrolizowanych najbardziej stabilna w wodzie i najefektywniejsza w destabilizacji koloidów jest forma $\mathrm{Al}_{13}$ o strukturze typu „Kegging”, w której centralny atom glinu z tetraedryczną koordynacją otoczony jest przez dwanaście leżących na krawędziach oktaedrycznie koordynowanych atomów glinu. Johansson [11] na podstawie badań krystalograficznych dokładnie określił przestrzenną strukturę polimeru $\mathrm{Al}_{13}$, która została potwierdzona za pomocą badań z wykorzystaniem spektroskopii NMR. O stężeniu polimeru $\mathrm{Al}_{13}$ w wodnych roztworach chlorków poliglinu współdecyduje ilość i sposób dawkowania zasady w czasie wytwarzania koagulantów. Według Guangjie i in. [8], w roztworach chlorków poliglinu uzyskuje się największy udział form polimerycznych o dużym ładunku dodatnim wówczas, gdy podczas wytwarzania koagulantu zasada dawkowana jest małymi porcjami. Parker i Kiriesi [18] uważają, że polimery $\mathrm{Al}_{13} \mathrm{~W}$ roztworach chlorków poliglinu są stabilne nawet przez kilka miesięcy w temperaturze 298 K i gdy wartość współczynnika alkaliczności (r) wynosi 2,4. Przywołani autorzy stwierdzili również, że stabilność ta maleje wraz ze wzrostem temperatury i zmniejszeniem się wartości współczynnika alkaliczności (r).

Zdaniem wielu autorów [6, 17, 19, 20, 21] obecność polimerycznych form glinu w roztworach chlorków poliglinu powoduje, że są one skuteczniejsze niż siarczan(VI) glinu w destabilizowaniu koloidów o ujemnym ładunku elektrycznym, usuwaniu zanieczyszczeń organicznych, a także zanieczyszczeń powodujących barwę i mętność wody. Stwierdzono również, że skuteczność chlorków poliglinu zwiększa się wraz ze wzrostem ich zasadowości.

Odegaard i współpracownicy [17] uważają, że niższe dawki koagulantów wstępnie zhydrolizowanych, zapewniające taką samą efektywność w usuwaniu zanieczyszczeń, wynikają z obecności w ich roztworach większej ilości polimerycznych kompleksów glinu o dużym dodatnim ładunku niż w roztworach koagulantów niezhydrolizowanych wstępnie. Ich zdaniem koagulanty wstępnie zhydrolizowane w porównaniu z niezhydrolizowanymi w mniejszym stopniu obniżają odczyn oczyszczanej wody. Do zalet koagulantów wstępnie

Tablica 1. Formy glinu w roztworach koagulantów wstępnie zhydrolizowanych [6]

\begin{tabular}{|c|c|c|c|}
\hline Autor & \multicolumn{2}{|c|}{ Monomery } & Polimery \\
\hline $\begin{array}{l}\text { Według Grahama i Jianga oraz } \\
\text { Odegaarda, Fettiga i Ratnaweera }\end{array}$ & \multicolumn{2}{|c|}{$\mathrm{Al}^{3+}, \mathrm{Al}(\mathrm{OH})^{2+}, \mathrm{Al}(\mathrm{OH})^{2+}, \mathrm{Al}(\mathrm{OH})^{4-}$} & $\begin{array}{l}{\left[\mathrm{Al}_{2}(\mathrm{OH})_{2}\right]^{4+},} \\
{\left[\mathrm{Al}_{3}(\mathrm{OH})_{4}\right]^{5+},\left[\mathrm{Al}_{13} \mathrm{O}_{4}(\mathrm{OH})_{24}\right]^{7+}}\end{array}$ \\
\hline Według Gillberga & \multicolumn{2}{|c|}{$\begin{array}{l}{\left[\mathrm{Al}\left(\mathrm{H}_{2} \mathrm{O}\right)_{6}\right]^{3+},\left[\mathrm{Al}(\mathrm{OH})\left(\mathrm{H}_{2} \mathrm{O}\right)_{5}\right]^{2+},} \\
{\left[\mathrm{Al}(\mathrm{OH})_{2}\left(\mathrm{H}_{2} \mathrm{O}\right)_{4}\right]^{+}}\end{array}$} & {$\left[\mathrm{Al}_{2}(\mathrm{OH})_{2}\left(\mathrm{H}_{2} \mathrm{O}\right)_{8}\right]^{4+},\left[\mathrm{Al}_{13} \mathrm{O}_{4}(\mathrm{OH})_{24}\left(\mathrm{H}_{2} \mathrm{O}\right)_{12}\right]^{7^{+}}$} \\
\hline $\begin{array}{l}\text { Według Bottero, Tchoubara, Casesa } \\
\text { i Fiessingera }\end{array}$ & \multicolumn{2}{|c|}{$\begin{array}{l}{\left[\mathrm{Al}\left(\mathrm{H}_{2} \mathrm{O}\right)_{6}\right]^{3+},\left[\mathrm{Al}(\mathrm{OH})\left(\mathrm{H}_{2} \mathrm{O}\right)_{5}\right]^{2+}} \\
{\left[\mathrm{Al}(\mathrm{OH})_{2}\left(\mathrm{H}_{2} \mathrm{O}\right)_{4}\right]^{+}}\end{array}$} & {$\left[\mathrm{AlO}_{4} \mathrm{Al}_{12}(\mathrm{OH})_{28}\right]^{3+}$} \\
\hline Według Morgana & \multicolumn{2}{|c|}{$\mathrm{Al}^{3+}, \mathrm{Al}(\mathrm{OH})^{2+}, \mathrm{Al}(\mathrm{OH})^{2+}, \mathrm{Al}(\mathrm{OH})^{4-}$} & $\begin{array}{l}{\left[\mathrm{Al}_{2}(\mathrm{OH})_{2}\right]^{4+}} \\
{\left[\mathrm{Al}_{7}(\mathrm{OH})_{17}\right]^{4+},\left[\mathrm{Al}_{13}(\mathrm{OH})_{34}\right]^{5+}}\end{array}$ \\
\hline \multirow[b]{2}{*}{$\begin{array}{l}\text { Według Bertrama, Mullera, Seefelda } \\
\text { i Gebnera }\end{array}$} & Monomery & Oligomery & Polimery \\
\hline & $\begin{array}{l}{\left[\mathrm{Al}(\mathrm{OH})_{6}\right]^{3+}} \\
\text { względnie } \\
{\left[\mathrm{Al}(\mathrm{OH})\left(\mathrm{H}_{2} \mathrm{O}\right)_{5}\right]^{2+}}\end{array}$ & $\begin{array}{l}\text { dimer: } \\
{\left[\mathrm{Al}_{2}(\mathrm{OH})_{2}\left(\mathrm{H}_{2} \mathrm{O}\right)_{8}\right]^{4+}} \\
\text { trimer: } \\
{\left[\mathrm{Al}_{3}(\mathrm{OH})\left(\mathrm{H}_{2} \mathrm{O}\right)_{9}\right]^{5+}}\end{array}$ & {$\left[\mathrm{AlO}_{4} \mathrm{Al}_{12}(\mathrm{OH})_{24}\left(\mathrm{H}_{2} \mathrm{O}\right)_{12}\right]^{7+}$} \\
\hline
\end{tabular}


zhydrolizowanych należy również ich mniejsza wrażliwość na niską temperaturę oraz zmiany $\mathrm{pH}$ oczyszczanej wody.

Opinie dotyczące optymalnych zakresów pH dla koagulantów nie są jednoznaczne. Według Dempseya [4], dla $\mathrm{Al}_{2}\left(\mathrm{SO}_{4}\right)_{3}$ $\mathrm{pH}=5,5 \div 7,0$, a dla chlorków poliglinu $\mathrm{pH}=4,0 \div 8,0$. Natomiast Odegaard [17] uważa, że zakresy te wynoszą odpowiednio $5,0 \div 6,0$ oraz $3,0 \div 9,0$.

Koagulanty wstępnie zhydrolizowane usuwają zanieczyszczenia w wyniku takich samych mechanizmów jak koagulanty niezhydrolizowane. Dzięki wstępnemu zhydrolizowaniu chlorki poliglinu charakteryzują się zwiększoną za- sadowością. W konsekwencji w mniejszym stopniu obniżają pH wody w porównaniu z siarczanem(VI) glinu czy żelaza, a tym samym powodują mniejszą intensyfikację korozyjności wody po koagulacji. Obecność większej ilości polikationowych produktów wstępnej hydrolizy i ich spolimeryzowanie umożliwiają skuteczniejszą neutralizację koloidalnych i rozpuszczonych zanieczyszczeń. Dzięki wymienionym właściwościom i zaletom koagulantów wstępnie zhydrolizowanych, chlorki poliglinu są coraz częściej stosowane w układach technologicznych oczyszczania wody, a zwłaszcza wody przeznaczonej do spożycia przez ludzi.

\section{Metodyka badań}

Ze względu na brak regularnej eksploatacji w dłuższym okresie czasu odwiertów udostępniających złoża węglowodorów w poziomach łupkowych do badań procesu oczyszczania przyjęto wodę o symulowanym składzie, opracowanym na podstawie badań literaturowych oraz analiz składu uzyskanych próbek cieczy po hydraulicznym szczelinowaniu [15]. Zawartość głównych zanieczyszczeń w badanej próbce wody złożowej zamieszczono w tablicy 2.

Do wstępnych badań koagulacji wytypowano stosowany standardowo siarczan(VI) glinu(III) oraz nowoczesne środki z grupy chlorków poliglinu: PAX XL 19, PAX XL 61, Flokor D15, Flokor 1,2A oraz Flokor 1ASW. Na podstawie danych literaturowych $[1,5,19]$ i przeprowadzonych badań ustalono optymalny odczyn dla koagulacji wykonanej z użyciem siarczanu glinu ( $\mathrm{pH} 6,0 \div 7,0$ ). Badania koagulacji prowadzono, używając wodę po napowietrzaniu.

Dla każdego koagulanta wykonano serię badań pozwalającą na ustalenie optymalnej dawki środka przy skorygowanym odczynie. Przeprowadzono badania porównawcze efektywności koagulacji po skorygowaniu odczynu wody i zastosowaniu optymalnych dawek koagulantów. Następnie wy- konano badania procesu koagulacji na wodzie bez korekty odczynu. Wytypowano jeden najbardziej efektywny koagulant, dla którego przeprowadzono dalsze testy w celu ustalenia optymalnej dawki w procesie bez korekty odczynu wody. Po określeniu optymalnej dawki środka wykonano testy $\mathrm{z}$ doborem dawki flokulanta. Zastosowano Stabpol K - nowoczesny środek o wysokiej efektywności.

Koagulację prowadzono w koagulatorze laboratoryjnym przy stałym czasie szybkiego mieszania wynoszącym 5 min (przy $200 \mathrm{obr} . / \mathrm{min})$ i wolnego - $15 \mathrm{~min}$ (20 obr./min). Objętości osadów pokoagulacyjnych odczytywano podczas sedymentacji w leju Imhoffa (dokładność odczytu: $0,5 \mathrm{~cm}^{3}$ do obj. $40 \mathrm{~cm}^{3}$ oraz $1 \mathrm{~cm}^{3}$ powyżej obj. $40 \mathrm{~cm}^{3}$ ).

Analizy fizykochemiczne: zawartość zawiesin - oznaczenie wagowe, przesączenie na sączkach $0,45 \mu \mathrm{m}$ i wysuszenie osadu w temperaturze $105^{\circ} \mathrm{C}$ do stałej masy, a także żelazo ogólne oznaczano za pomocą spektrofotometru UV/VIS Lambda 35. TPH określono metodą ekstrakcji do fazy stałej (SPE) na kolumienkach z fazą oktadecylową, a następnie oczyszczano na wypełnieniu Florisil. Wskaźnik $\mathrm{ChZT}_{(\mathrm{Cr})}$ oznaczano na testach kuwetowych za pomocą spektrofotometru UV/VIS Lambda 35.

\section{Wyniki badań procesu koagulacji po korekcie odczynu wody}

W celu dokonania wyboru środków chemicznych umożliwiających prowadzenie procesu koagulacji bez korekty (lub z niewielką korektą odczynu wody) przeprowadzono testy laboratoryjne wytypowanych nowoczesnych koagulantów glinowych (chlorków poliglinu) w porównaniu ze standardowo stosowanym siarczanem glinu.

Do badań wybrano zestaw koagulantów o zróżnicowanej charakterystyce:

- $\operatorname{PAX}$ XL $61-\mathrm{pH}=3$; zawartość $\mathrm{Al}^{3+}=5,4 \%$; zasadoWOŚć $70 \%$,

- $\quad$ PAX XL 19F - pH = 4; zawartość $\mathrm{Al}^{3+}=8,5 \%$; zasadowość $85 \%$,
- Flokor D15 - pH =4,2; zawartość $\mathrm{Al}^{3+}=6,5 \%$; zasadowość 85\%,

- Flokor 1,2 A-pH = 4,2; zawartość $\mathrm{Al}^{3+}=12,0 \%$; zasadowość 85\%,

- Flokor $1 \mathrm{ASW}-\mathrm{pH}=3,8$; zawartość $\mathrm{Al}^{3+}=9,0 \%$; zasadowość $85 \%$; siarczany $0,8 \%$.

$\mathrm{W}$ celu skrócenia procedury badawczej zadecydowano o stosowaniu stałej dawki sprawdzonego, wydajnego flokulanta Stabpol K w ilości $0,75 \mathrm{mg} / \mathrm{dm}^{3}$.

Przeprowadzono testy mające na celu dobór optymalnych dawek wytypowanych środków chemicznych (tablica 2, rysunki 1-3). W wyniku badań stwierdzono, że dla 

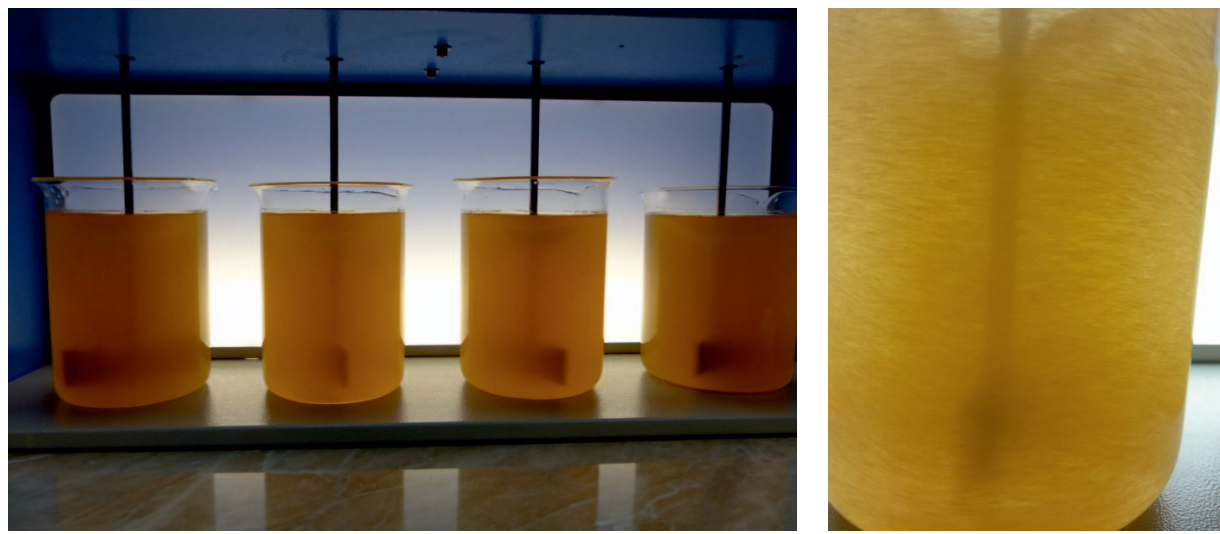

Rys. 1. Woda surowa przygotowana do badań procesu koagulacji i etap szybkiego mieszania z udziałem koagulanta. Widoczne powstające kłaczki osadów (fot. P. Jakubowicz)
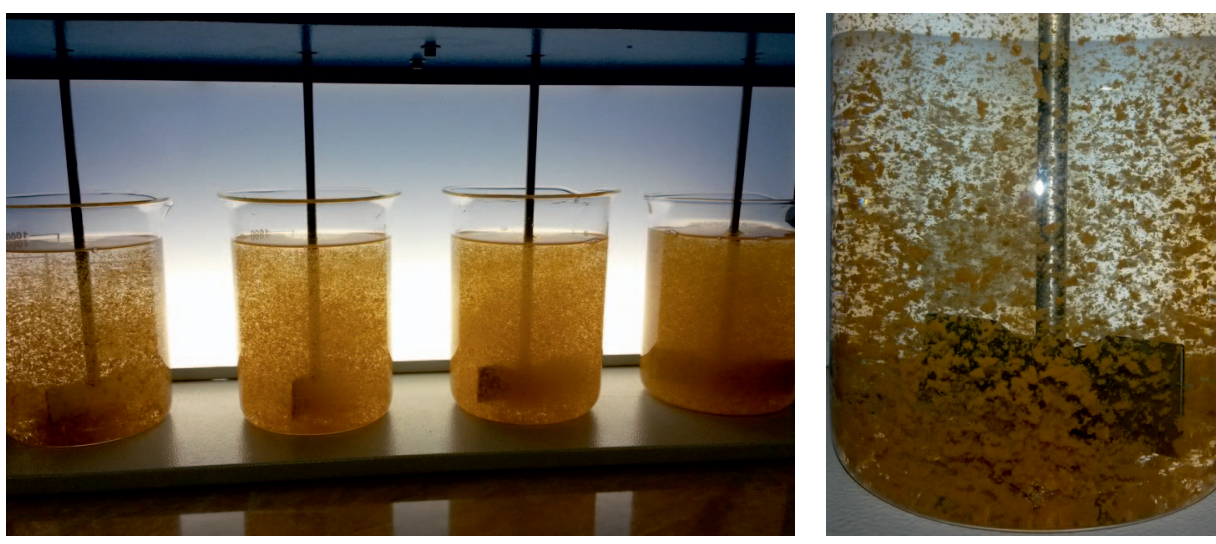

Rys. 2. Etap wolnego mieszania z udziałem flokulanta - narastanie kłaczków osadów i zbijanie się w duże konglomeraty (fot. P. Jakubowicz)

a)

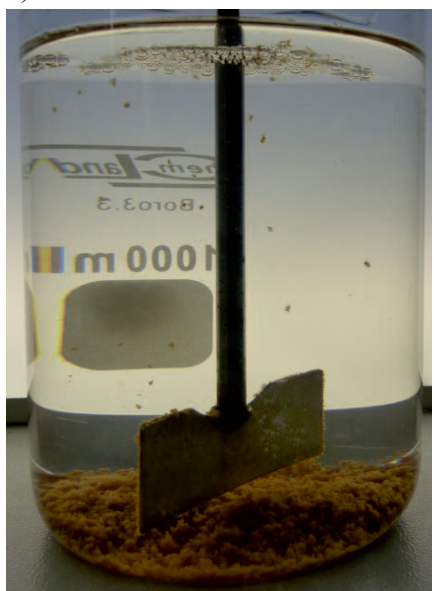

b)

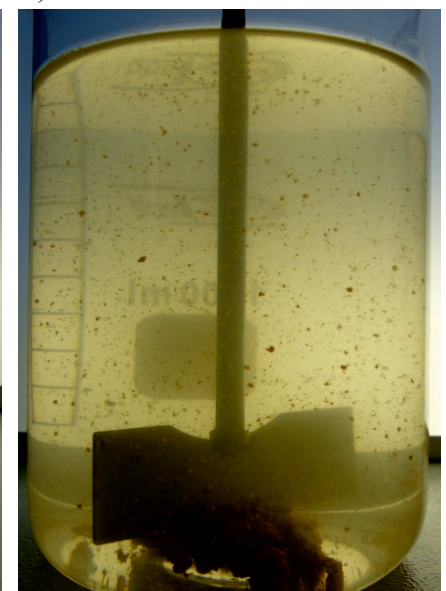

Rys. 3. Sedymentacja osadów: a) po prawidłowo, b) po nieprawidłowo przeprowadzonej koagulacji (widoczna mętność w całej objętości i trudno sedymentujące drobne cząstki osadów) (fot. P. Jakubowicz) próbki wody złożowej po napowietrzaniu i korekcie odczynu optymalne dawki nowoczesnych koagulantów (chlorków poliglinu) są zróżnicowane, jednak znacznie niższe niż w przypadku siarczanu glinu (rysunki 4 i 5 , tablice 2 i 3).

Najbardziej efektywnym spośród testowanych koagulantów okazał się środek Flokor 1ASW, który charakteryzuje się wysoką zasadowością (85\%), wysoką zawartością glinu $(9,0 \%)$ oraz dodatkiem siarczanów(VI) (0,8\%). Już dawka 50 mg/dm ${ }^{3}$ pozwoliła na uzyskanie bardzo dobrej koagulacji osadów (rysunek 5).

Ze zbliżoną efektywnością proces koagulacji przebiegał przy wykorzystaniu środka o nazwie Flokor 1,2A. Nieco większa dawka środka $\left(60 \mathrm{mg} / \mathrm{dm}^{3}\right)$ sprawiła, że uzyskiwano podobne objętości osadów pokoagulacyjnych.

Zawartość wybranych typów zanieczyszczeń w wodzie po korekcie odczynu i przeprowadzeniu procesu koagulacji z zastosowaniem badanych środków przedstawiono w tablicy 3.

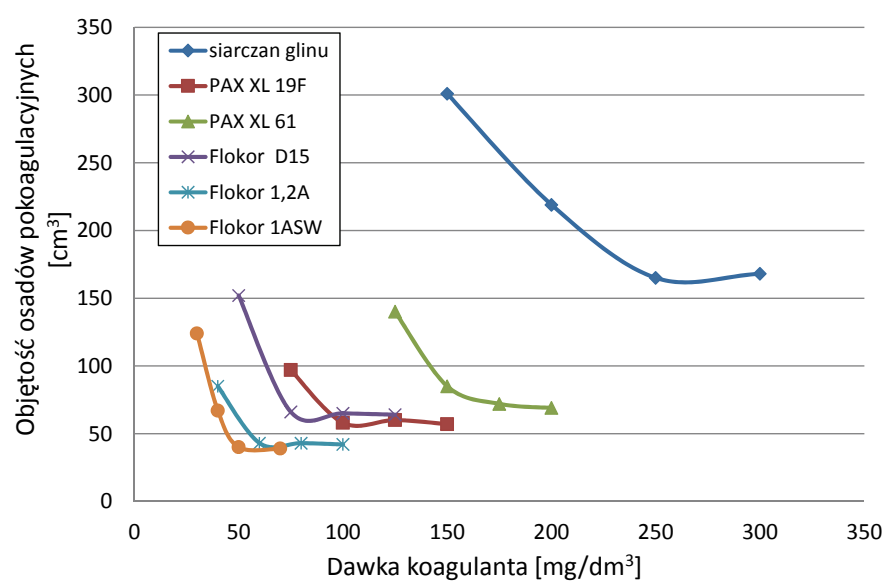

Rys. 4. Dobór dawek badanych środków w procesie koagulacji wody złożowej z formacji łupkowych o symulowanym składzie

Tablica 2. Zestawienie optymalnych dawek wytypowanych rodzajów koagulantów dla wody złożowej po korekcie odczynu

\begin{tabular}{|l|c|c|c|c|c|c|}
\cline { 2 - 7 } \multicolumn{1}{c|}{} & \multicolumn{5}{c|}{ Koagulant } \\
\cline { 2 - 8 } \multicolumn{1}{c|}{} & siarczan glinu & PAX XL 19F & PAX XL 61 & Flokor D15 & Flokor 1,2A & Flokor 1ASW \\
\hline Optymalna dawka $\left[\mathrm{mg} / \mathrm{dm}^{3}\right]$ & 250 & 100 & 175 & 75 & 60 & 50 \\
\hline
\end{tabular}


Najwyższą efektywnością cechowały się dwa środki: Flokor 1,2A oraz Flokor 1ASW. W ich przypadku usunięcie poszczególnych typów zanieczyszczeń odnotowano na najwyższym poziomie: zawiesiny i żelazo

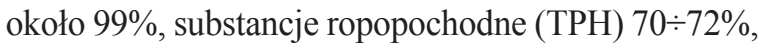
utlenialność $\left(\mathrm{ChZT}_{(\mathrm{Cr})}\right)$ około 63\%. Pozostałe środki charakteryzowały się niewiele niższą efektywnością i ich zastosowanie skutkowało obniżeniem zawartości poszczególnych zanieczyszczeń na poziomie: zawiesiny od 93 do $95 \%$, żelazo od 91 do 95\%, TPH od 53 do $63 \%$ i utlenialność od 43,5 do $58 \%$.

Rys. 5. Porównanie wpływu badanych środków na efektywność procesu koagulacji wody złożowej (po korekcie odczynu)

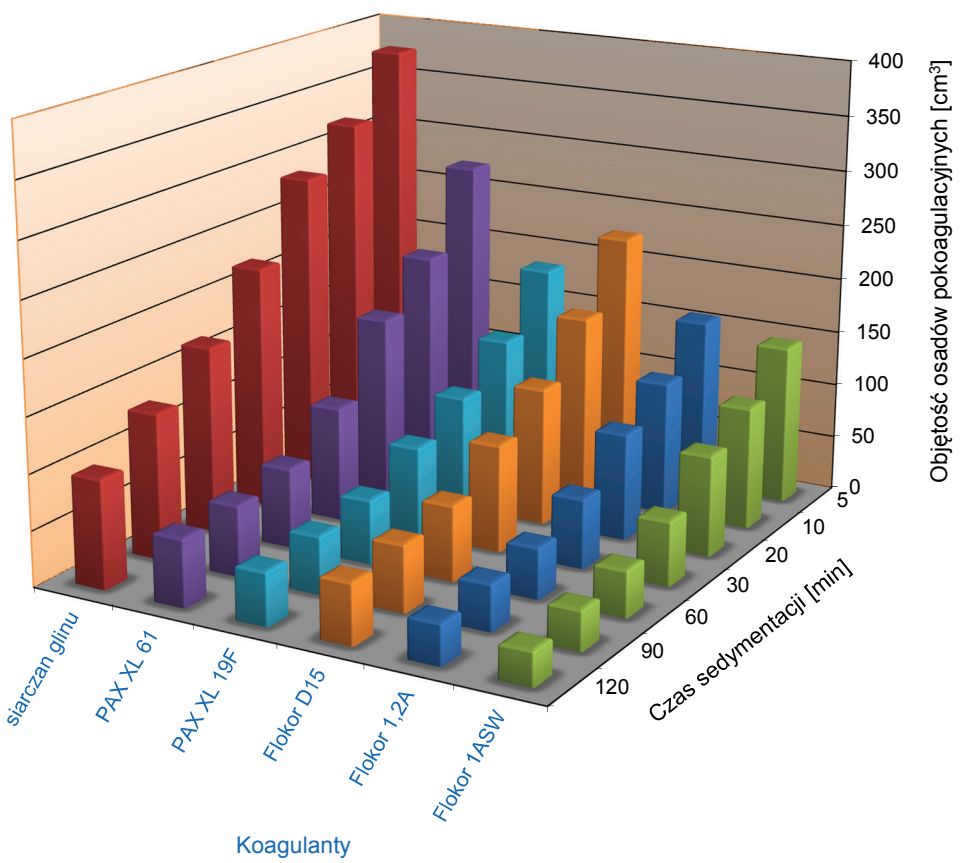

Tablica 3. Zawartości zanieczyszczeń pozostałych w wodzie złożowej po korekcie odczynu i koagulacji przeprowadzonej badanymi środkami

\begin{tabular}{|l|c|c|c|c|c|c|c|}
\hline \multirow{2}{*}{ Oznaczany parametr } & \multirow{2}{*}{$\begin{array}{c}\text { Woda } \\
\text { surowa }\end{array}$} & \multicolumn{5}{|c|}{ Woda po koagulacji z zastosowaniem środka } \\
\cline { 3 - 8 } & & siarczan glinu & PAX XL 61 & PAX XL 19F & Flokor D15 & Flokor 1,2A & Flokor 1ASW \\
\hline Zawiesiny $\left[\mathrm{mg} / \mathrm{dm}^{3}\right]$ & $440 \pm 20$ & $31 \pm 2,5$ & $28 \pm 2,2$ & $25 \pm 2,0$ & $22 \pm 1,7$ & $5,0 \pm 0,5$ & $3,0 \pm 0,3$ \\
\hline Żelazo $\left[\mathrm{mg} / \mathrm{dm}^{3}\right]$ & $42 \pm 2,1$ & $3,5 \pm 0,07$ & $2,7 \pm 0,05$ & $2,1 \pm 0,05$ & $1,6 \pm 0,03$ & $0,50 \pm 0,01$ & $0,40 \pm 0,01$ \\
\hline TPH $\left[\mathrm{mg} / \mathrm{dm}^{3}\right]$ & $74,2 \pm 7,0$ & $34,7 \pm 3,1$ & $32,4 \pm 3,0$ & $28,2 \pm 2,5$ & $27,1 \pm 2,4$ & $21,8 \pm 1,9$ & $20,7 \pm 1,8$ \\
\hline $\mathrm{ChZT}_{(\mathbf{C r})}\left[\mathrm{mg} \mathrm{O}_{2} / \mathrm{dm}^{3}\right]$ & $2640 \pm 53$ & $1490 \pm 29$ & $1258 \pm 25$ & $1139 \pm 22$ & $1109 \pm 22$ & $986 \pm 19$ & $965 \pm 19$ \\
\hline
\end{tabular}

\section{Wyniki badań procesu koagulacji bez korekty odczynu wody}

Kolejny etap badań polegał na przeprowadzeniu koagulacji na próbce wody złożowej po napowietrzaniu, jednak bez korygowania odczynu. W trakcie napowietrzania w wyniku procesów odgazowania i utleniania zachodzą różnego rodzaju reakcje chemiczne powodujące m.in. zmianę odczynu wody. W przypadku badanej wody następuje jej zakwaszenie (obniżenie odczynu) do $\mathrm{pH}=4,9$. Może to spowodować przesunięcie odczynu wody poza optymalny zakres dla zastosowania siarczanu glinu. $Z$ tego powodu przeprowadzono testy dla różnych rodzajów polichlorków glinu, które charakteryzują się efektywnym działaniem w szerszym zakresie $\mathrm{pH}$. Uzyskane wyniki badań przedstawiono na rysunku 6 i w tablicy 4 .

Najbardziej efektywnie działające środki, podobnie jak w przypadku koagulacji z korektą odczynu, to Flokor 1ASW oraz porównywalny Flokor 1,2A. Uzyskane objętości osadów były zbliżone przy zachowanych wielkościach zastosowanych dawek jak w poprzedniej serii badań (po korekcie odczynu). Pozostałe badane

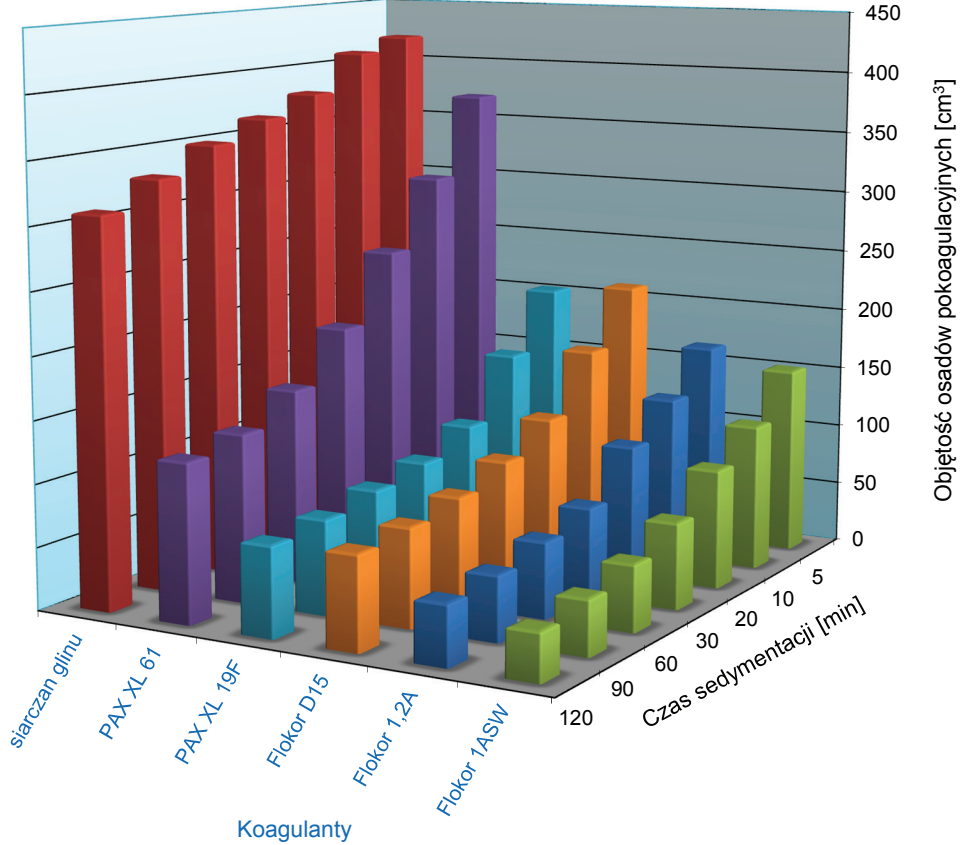

Rys. 6. Porównanie wpływu badanych środków na efektywność procesu koagulacji wody złożowej (bez korekty odczynu) 
nowoczesne środki również dawały pozytywny efekt koagulacji, jednak konieczne było zwiększenie dawek, a w przypadku środka PAX XL 61 faza wodna po koagulacji pozostała mętna.

Najgorzej koagulacja przebiegła przy użyciu jako koagulanta siarczanu(VI) glinu(III). Lekko kwaśny odczyn wody spowodował przekroczenie zakresu $\mathrm{pH}$, w jakim koagulant powinien być stosowany i po procesie koagulacji uzyskano bardzo drobny osad, a faza wodna pozostała mętna nawet po 2-godzinnej sedymentacji.

Obniżenie zawartości zanieczyszczeń w wodzie po koagulacji przeprowadzonej bez korekty odczynu dla poszczególnych środków przedstawiono w tablicy 4. Najwyższą efektywność uzyskano ponownie w przypadku dwóch koagulantów: Flokor 1,2A i Flokor 1ASW. Redukcja zawartości zanieczyszczeń kształtowała się na zbliżonym poziomie do procesu koagulacji przeprowadzonego po korekcie odczynu wody i wynosiła odpowiednio (Flokor 1,2A i Flokor 1ASW): zawiesiny $97,3 \%$ i 99,09\%, żelazo 98,1\% i 98,8\%, TPH 66,6\% i 71,3\% oraz utlenialność 57,1\% i 61,4\%. Uzyskane wyniki świadczą o dobrej skuteczności działania tych środków w procesie oczyszczania wody o lekko kwaśnym odczynie.

Koagulacja wody złożowej bez korekty odczynu przeprowadzona za pomocą pozostałych badanych środków okazała się mniej efektywna niż w przypadku wody ze skorygowanym odczynem. Środki PAX XL 19F i Flokor D15 pozwoliły na uzyskanie znacznego obniżenia zawartości zanieczyszczeń, wynoszącego odpowiednio: zawiesiny $85,2 \%$ i $91,4 \%$, żelazo $65,2 \%$ i $91,9 \%$, TPH $36,2 \%$ i $54,6 \%$ oraz $\mathrm{ChZT}_{(\mathrm{Cr})} 29,4 \%$ i 43,8\%. Pozostałe dwa środki nie są wystarczająco skuteczne do przeprowadzenia procesu koagulacji przy odczynie lekko kwaśnym ( $\mathrm{pH} \sim 5$ ). Zwłaszcza w przypadku siarczanu glinu koagulacja praktycznie nie miała miejsca.

W przypadku braku korekty oczyszczanej wody należy brać pod uwagę fakt, że obniżenie odczynu (zakwaszenie wody) może spowodować zmniejszenie efektywności utleniania żelaza $\mathrm{w}$ procesie napowietrzania.

Tablica 4. Zawartości zanieczyszczeń pozostałych w wodzie złożowej po koagulacji przeprowadzonej badanymi środkami bez korekty odczynu

\begin{tabular}{|c|c|c|c|c|c|c|c|}
\hline \multirow{2}{*}{ Oznaczany parametr } & \multirow{2}{*}{$\begin{array}{l}\text { Woda } \\
\text { surowa }\end{array}$} & \multicolumn{6}{|c|}{ Woda po koagulacji z zastosowaniem środka } \\
\hline & & siarczan glinu & PAX XL $61^{*}$ & PAX XL 19F & Flokor D15 & Flokor 1,2A & Flokor 1ASW \\
\hline Zawiesiny $\left[\mathrm{mg} / \mathrm{dm}^{3}\right]$ & $440 \pm 20$ & \multirow{4}{*}{$\begin{array}{c}\text { brak } \\
\text { koagulacji } \\
\text { zanieczyszczeń }\end{array}$} & $217 \pm 10$ & $65 \pm 5,2$ & $38 \pm 3,0$ & $12 \pm 0,9$ & $4,0 \pm 0,3$ \\
\hline Żelazo $\left[\mathrm{mg} / \mathrm{dm}^{3}\right]$ & $42 \pm 2,1$ & & $29,3 \pm 1,5$ & $14,6 \pm 0,7$ & $3,6 \pm 0,18$ & $0,8 \pm 0,04$ & $0,5 \pm 0,01$ \\
\hline $\mathrm{TPH}\left[\mathrm{mg} / \mathrm{dm}^{3}\right]$ & $74,2 \pm 7,0$ & & $62,9 \pm 5,6$ & $47,3 \pm 4,2$ & $33,7 \pm 3,0$ & $24,8 \pm 2,2$ & $21,3 \pm 1,9$ \\
\hline $\mathrm{ChZT}_{(\mathrm{Cr})}\left[\mathrm{mg} \mathrm{O}_{2} / \mathrm{dm}^{3}\right]$ & $2640 \pm 53$ & & $2236 \pm 44$ & $1865 \pm 37$ & $1485 \pm 29$ & $1132 \pm 22$ & $1020 \pm 20$ \\
\hline
\end{tabular}

* Pozostaje wyraźna mętność oczyszczanej wody.

\section{Podsumowanie}

Udział głównych grup zanieczyszczeń obecnych w wydobywanych wodach złożowych $\mathrm{z}$ formacji łupkowych jest podobny do wód ze złóż konwencjonalnych. Należą do nich: osady i zawiesiny, jony metali (żelaza i manganu) oraz substancje ropopochodne.

Cały proces oczyszczania wstępnego opiera się na standardowych technikach, jest dosyć prosty i mało rozbudowany technologicznie. Zróżnicowane zawartości zanieczyszczeń i specyfika prowadzenia poszczególnych etapów oczyszczania wymaga jednak korygowania parametrów procesu praktycznie dla każdej partii oczyszczanych wód złożowych. Szczególnie ważny jest etap koagulacji z flokulacją, który decyduje o uzyskanych efektach oczyszczania.

Przeprowadzenie badań procesu koagulacji dla danej wody złożowej pozwala na właściwy dobór rodzaju koagulanta zapewniającego możliwie najbardziej efektywne działanie. Laboratoryjna kontrola procesu koagulacji podczas pracy instala- cji pozwala na taką korektę właściwości wody złożowej, która umożliwi poprawne przeprowadzenie etapu koagulacji i uzyskanie wysokiej skuteczności działania środków. Stosowanie optymalnych dawek, dobranych dla konkretnej partii oczyszczanej wody, zapewni usunięcie maksymalnej ilości zanieczyszczeń i zapobiegnie powstawaniu nadmiernych ilości osadów (zbyt mała dawka powoduje niedostateczne oczyszczenie, przedawkowanie - wzrost ilości osadów pokoagulacyjnych).

W trakcie procesu doboru środków chemicznych należy zwrócić uwagę na nowoczesne koagulanty, które pozwalają obniżyć dawki oraz uprościć proces, łagodząc wymogi dotyczące jego parametrów, a zwłaszcza odczynu oczyszczanej wody. Dzięki temu etap korekty odczynu może zostać w znacznej mierze uproszczony, a w niektórych przypadkach nawet całkowicie wyeliminowany, co przekłada się na wymierne korzyści ekonomiczne. Zastosowanie nowoczesnych i wydajnych środków, działających efektywnie także w niższych 
zakresach pH wody (odczyn kwaśny), może zaowocować obniżeniem ilości uzyskiwanych osadów pokoagulacyjnych, uproszczeniem procesu oddzielania otrzymanych osadów pokoagulacyjnych oraz zabezpieczeniem przed wprowadzaniem do odwiertów chłonnych dodatkowych zawiesin powstających przy niewłaściwie wykonanej koagulacji.

Prawidłowe przeprowadzenie procesu wstępnego oczyszczania pozwoli na przygotowanie wody złożowej do zagospo- darowania (zarówno do zatłoczenia do horyzontu chłonnego, jak i do zawadniania złóż w procesach wspomagających eksploatację) oraz przyczyni się do wydłużenia czasu bezawaryjnej pracy odwiertów zatłaczających. Wdrożenie procesu zatłaczania do złoża powinno zostać poprzedzone badaniami kompatybilności wody zatłaczanej z wodami wgłębnymi w celu uniknięcia niepożądanych zjawisk mogących prowadzić do kolmatacji strefy przyodwiertowej.

Prosimy cytować jako: Nafta-Gaz 2017, nr 3, s. 169-176, DOI: 10.18668/NG.2017.03.04

Artykuł nadesłano do Redakcji 22.06.2016 r. Zatwierdzono do druku 20.01.2017 r.

Publikację przygotowano w oparciu o wyniki badań prowadzonych w ramach projektu pt.: Opracowanie optymalnych koncepcji zagospodarowania złóż niekonwencjonalnych z uwzględnieniem aspektów środowiskowych $i$ społecznych, finansowanego ze środków Narodowego Funduszu Badań i Rozwoju, projekt Blue Gas - Polski Gaz Łupkowy, umowa BGI Res Dev/13.

\section{Literatura}

[1] American Water Works Association: Operational Control of Coagulation and Filtration Processes. AWWA Manual M37, Third Edition, Denver 2011.

[2] Bader M.S.H.: Sulfate scale problems in oil fields water injection operations. Desalination 2006, vol. 201, s. 100-105.

[3] Chmiel A.: Wpływ biochemicznych przemian zanieczyszczeń na ich podatność na koagulację. Praca doktorska, Politechnika Wrocławska, Wydział Inżynierii Srodowiska, 2009.

[4] Dempsey B.A., Ganho R.M., O'Melia C.R.: The coagulation of humic substances by means of aluminium salts. JAWWA 1984, s. 141-151.

[5] Dzięgielewska M., Kossuth A., Fligier M.: Badanie wtaściwości koagulacyjnych polichlorku glinu. Zeszyty Naukowe Politechniki Śląskiej, Seria: Chemia 1998, z. 137, s. 37-47.

[6] Edzwald D.K., Pernitsky D.J., Parmenter W.L.: Polyaluminum coagulants for drinking water treatment, chemistry and selection. Chemical Water and Wastewater Treatment VI, Springer-Verlag 2000

[7] Edzwald J.K., van Benschoten J.E.: Aluminum coagulation of natural organic matter. Chemical Water and Wastewater Treatment, Springer-Verlag 1990.

[8] Guangjie Lu, Jiuhui Qu, Tang H.: The electrochemical production of highly effective polyaluminum chloride. Water Research 1990, nr 3, s. 807-812.

[9] Jakubowicz P., Steliga T., Bąk W.: Analiza wptywu wytypowanych zanieczyszczeń na proces zatłaczania wód złożowych $i$ ścieków do horyzontów chłonnych. Wiertnictwo Nafta Gaz 2006, t. 25, z. 2, s. 813-820.

[10] Jakubowicz P., Steliga T.: Assessment of the Main Threats to Injection Well Damage Caused by Reservoir Waters using AquaChem Software as well as Laboratory Tests Application. Nafta-Gaz 2012, nr 10, s. 655-660.

[11] Johansson G.: The crystal structure of some basic aluminum salts. Acta Chem. Scand. 1960, vol. 14, s. 771-773.
[12] Kowal A.L., Świderska-Bróż M.: Oczyszczanie wody. PWN, Warszawa-Wrocław 2007.

[13] Krupińska I.: Przydatność koagulacji w oczyszczaniu wody podziemnej ze szczególnym uwzględnieniem usuwania związków żelaza. Rozprawa doktorska, Wrocław 2006.

[14] Lewkiewicz-Małysa A., Konopka E.: Ochrona naturalnych właściwości zbiornikowych górotworu jako sktadowiska odpadowych wód złożowych. Górnictwo i Geoinżynieria 2009, z. 4, s. 177-188.

[15] Lubaś J., Kluk D.: An attempt to determine the chemical composition of reservoir waters from Polish Lower Paleozoic shale formations. Nafta-Gaz 2015, nr 11, s. 877-883.

[16] Nawrocki J., Biłozor S.: Uzdatnianie wody, procesy chemiczne i biologiczne. PWN, Warszawa-Poznań 2010.

[17] Odegaard H., Fettig J., Ratnaweera H.C.: Coagulation with prepolymerized metals salts. Chemical Water and Wastewater Treatment, Springer-Verlag 1990.

[18] Parker W.O., Kiriesi I.R.E.: Aluminium complexes in partially hydrolyzed aqueous $\mathrm{AlCl}_{3}$ solutions used to prepare pillared clay catalysts. Applied Catalysis General 1995, s. 121.

[19] Pernitsky D.J., Edywald J.K.: Selection of Alum and Polyaluminium Coagulants Principles and Applications. Journal of Water Supply Research and Technology Aqua 2006, vol. 55, nr 2, s. 121-141.

[20] Smoczyński L., Muńska K.T., Kosobucka M., Pierożyński B., Wardzyńska R., Załęska-Chróst B.: Destabilizacja ścieków modelowych $w$ procesie koagulacji chemicznej. Proceedings of ECOpole 2013, vol. 7, nr 1, s. 399-404.

[21] Zamfiroiu E., Masu S.: Aspects Regarding the Efficiency of Coagulation Process for Some Surface Waters. Chem. Bull. "Politechnica" Univ. (Timisoara) 2007, vol. 52(66), nr 1-2, s. $71-73$

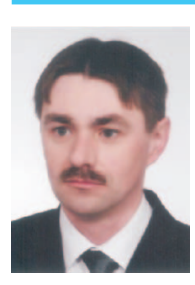

Mgr Piotr JAKUBOWICZ

Starszy specjalista badawczo-techniczny w Zakładzie Technologii Eksploatacji Płynów Złożowych. Instytut Nafty i Gazu - Państwowy Instytut Badawczy ul. Lubicz 25 A

31-503 Kraków

E-mail:piotr.jakubowicz@inig.pl

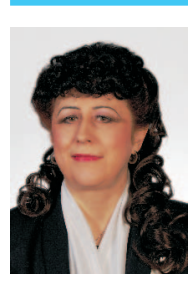

Prof. nzw. dr hab. inż. Teresa STELIGA Kierownik Zakładu Technologii Eksploatacji Płynów Złożowych. Instytut Nafty i Gazu - Państwowy Instytut Badawczy ul. Lubicz 25 A

31-503 Kraków

E-mail: teresa.steliga@inig.pl 